\title{
BANK INDONESIA RATE STANDARDS IN DETERMINING THE FINANCING OF MUDHARABAH IN BANK MUAMALAT INDONESIA
}

\author{
Rifqi Arief Aminullah \\ Institut Agama Islam Darussalam (IAID) Ciamis-Jawa Barat \\ Email: rifqiarief.aminullah@iaid.ac.id \\ Rizky Maidan Ilmy \\ Institut Agama Islam Darussalam (IAID) Ciamis-Jawa Barat \\ Riyan Gita Suara \\ Institut Agama Islam Darussalam (IAID) Ciamis-Jawa Barat \\ Received: 13 Dec 2020 \\ Accepted: 4 Feb 2021
}

\begin{abstract}
The purpose of this study was to determine how the effect of BI Rate and profit sharing rate to mudharabah financing income. This research was conducted at PT Bank Muamalat Indonesia which is the first syariah bank that stands in Indonesia which is purely syari'ah. This research is quantitative research, the method used in this research is associative (relationship) supported by document analysis approach, where the object of research is PT Bank Muamalat Indonesia, the sample used is monthly financial statements of PT Bank Muamalat Indonesia period 2018 -202O. The type of data used is secondary data obtained from financial reports published by BI, OJK and through the official website of PT Bank Muamalat Indonesia. Data analysis method used is descriptive analysis and panel data regression model with significance level $5 \%$ or 0,05 , then to process data using application Eviews 7 . The result of the analysis shows that partial rate of BI Rate and Profit Sharing (TBH) has positive and significant effect to Mudharabah Financing Income, proved by probability value of BI Rate $0,0024<0,05$, and probability value of profit sharing rate $0,0000<0.05$. Together, the BI Rate and Profit Sharing Ratios have a significant effect on Mudharabah Financing Income, this is evidenced by the value of the probability F statistic 0.000 which is less than 0.05. The variables of the BI Rate and the Profit Sharing Rate have contributed to explain Mudharabah Financing Revenue of 83.3\%, while the remaining $16.7 \%$ (100\% $83.3 \%$ ) is explained by other variables not examined or excluded in this research model , so it can be concluded that the BI Rate and profit sharing rate have a positive and significant impact on mudharabah financing income either individually or jointly.
\end{abstract}

\begin{abstract}
Abstrak
Penelitian ini bertujuan untuk mengetahui pengaruh BI Rate dan tingkat bagi hasil terhadap pendapatan pembiayaan mudharabah. Penelitian ini dilakukan pada PT Bank Muamalat Indonesia yang merupakan bank syariah pertama yang berdiri di Indonesia yang murni syariah. Penelitian ini merupakan penelitian kuantitatif, dengan metode asosiatif (hubungan) yang didukung dengan pendekatan analisis dokumen, di mana objek penelitiannya adalah PT Bank Muamalat Indonesia. Sampel yang digunakan adalah laporan keuangan bulanan PT Bank Muamalat Indonesia periode 2018-202O. Jenis data yang digunakan adalah data sekunder yang diperoleh dari laporan keuangan yang diterbitkan oleh BI, OJK dan melalui website resmi PT Bank Muamalat Indonesia. Metode analisis data yang digunakan adalah analisis deskriptif dan model regresi data panel dengan taraf signifikansi $5 \%$ atau 0,05 , selanjutnya untuk mengolah data menggunakan aplikasi Eviews 7. Hasil analisis menunjukkan bahwa secara parsial BI
\end{abstract}


Rate dan Bagi Hasil (TBH) memiliki berpengaruh positif dan signifikan terhadap Pendapatan Pembiayaan Mudharabah, dibuktikan dengan nilai probabilitas BI Rate $0,0024<0,05$, dan nilai probabilitas tingkat bagi hasil 0 , 0000 $<0,05$. Secara bersama-sama BI Rate dan Profit Sharing Ratio berpengaruh signifikan terhadap Pendapatan Pembiayaan Mudharabah, hal ini dibuktikan dengan nilai probabilitas F statistik 0,000 yang lebih kecil dari 0,05. Variabel BI Rate dan Profit Sharing Rate telah memberikan kontribusi untuk menjelaskan Pendapatan Pembiayaan Mudharabah sebesar 83,3\%, sedangkan sisanya 16,7\% (100\% - 83,3\%) dijelaskan oleh variabel lain yang tidak diteliti atau dikecualikan dalam model penelitian ini, sehingga dapat disimpulkan bahwa BI Rate dan profit sharing rate berpengaruh positif dan signifikan terhadap pendapatan pembiayaan mudharabah baik secara sendiri-sendiri maupun bersama-sama.

Keywords: Mudharabah Financing, BI Rate and Profit Sharing (TBH).

\section{Introduction}

Bank Syari'ah in Law no. 21 year 2008, Bank Syari'ah is a Bank conducting its business activities based on sharia principles and according to its type consisting of Syari'ah Commercial Bank and Shari'ah People's Financing Bank. One of the functions of the establishment of Islamic banking is to direct Muslims in carrying out Islamic muamalahnya activities, and avoid the practice of usury and other practices that contain elements of gharar, where the types of business is prohibited in addition to Islam also has a negative impact on the life of the community economy (Huda \& Heykal, 2010: 39).

Therefore, Syari'ah Bank comes with the principle of profit sharing and abolish the interest system which in Islam is clearly haram, the principle of profit sharing in Bank Syari'ah such as through financing with mudharabah and musyarakah, but which is often used financing with mudharabah contract. In fact, Bank Syari'ah has weakness among the customers who are not loyal to syari'ah banking, because they compare the percentage of profit sharing in Bank Syari'ah with interest rate in Conventional Bank. By a margin of about two percent (from the interest rate of Conventional Bank), this segment of customers is still loyal to the Bank Syari'ah. However, if more than that customers can move to a Conventional Bank (Al-Arif, 2010: 120).

Other facts found in the research conducted by Suma, etc. (2018) show that the number of respondents who presented interest rate or profit sharing as a reference in choosing Bank is almost balanced, as many as $41.88 \%$ of respondents said they chose Bank based on offer of interest rate or high profit sharing . As for $43.83 \%$ of respondents stated that interest rate or profit sharing is not their reason in Bank selection. The rest, ie $\mathbf{1 4 . 2 9 \%}$ of respondents expressed doubt. In this case indirectly proves that Indonesian banking customers are still much rational by paying attention to the offer of interest rate and high profit sharing in Bank selection (Al-Arif, 2010: 121).

This is in line with that disclosed by Barno Sudarwanto as a practitioner at a syariah financial institution that said when the BI Rate increased it will affect the sharia banking although not directly affect, but Bank Syari'ah more focused on liquidity risk and credit risk or financing and Bank Syari'ah must be careful in issuing financing. Then the increase of BI Rate to 7 percent has an effect on sharia banking financing 
business. Because the cost of funds to be expensive because there is a significant increase. Syari'ah banking is now cautious in channeling financing.

Then in a study conducted by Widiyanto \& Diyani (2020), in the study entitled analysis of the influence of BI interest rate on mudharabah financing, which shows that BI interest rate has significant effect on mudharabah financing. Giannini (2020), in his research entitled factors affecting mudharabah financing at a Syari'ah Commercial Bank in Indonesia, one of the factors affecting mudharabah financing is profit sharing, which has a positive effect on mudharabah financing.

By looking at the above background, the researcher took a case study at PT Bank Muamalat Indonesia with the focus of the problem on financing in the mudharabah contract. Bank Muamalat Indonesia is a bank that is very proven not wobble at all with the monetary crisis that hit Indonesia in 1998. With the interest-free system is one of the superior products of Bank Muamalat Indonesia which has brought eksisnya syari'ah banking in Indonesia until now.

Although sharia banks do not use the interest system but use the profit sharing system, with the increase of BI Rate will affect the financing income of Bank Syari'ah, therefore the researcher is interested to conduct research with the title of BI Rate Standard on Mudharabah Bank Funding in Bank Muamalat Indonesia.

\section{Theoretical Review}

The Concept of BI Rate

BI Rate is a policy rate reflecting the stance or stance of monetary policy stipulated by Bank Indonesia and announced to the public. The BI Rate is announced by the Board of Governors of Bank Indonesia at each monthly Board of Governors Meeting and implemented in monetary operations conducted by Bank Indonesia through liquidity management in the money market to achieve the operational targets of monetary policy, monetary policy operational goals reflected in the development of the Money Market interest rate Inter Bank Overnight (PUAB O / N). The movement in the interbank money market rate is expected to be followed by developments in deposit rates, and in turn bank lending rates. Taking into account other factors in the economy, Bank Indonesia will generally raise the BI Rate if future inflation is predicted to exceed the predetermined target, whereas Bank Indonesia will lower the BI Rate if future inflation is predicted to fall below pre-determined targets.

\section{Interest Rate Concept}

According to Muhammad (2002: 40), "Interest is dependent on borrowing money, which is usually expressed as a percentage of money lent". In the view of Karl and Fair, "The interest rate is the annual interest payment of a loan, in the form of a percentage of the loan obtained from the amount of interest earned annually divided by the loan amount" (Karl and Fair, 2001: 635).

Meanwhile, according Sunariyah (2018: 82), "Interest rates are the price of the loan. The interest rate is expressed as a percentage of the principal amount of time perunit. Interest is a measure of the price of a resource used by a debtor paid to a creditor. Time units are usually expressed in one year (one year of investment) or may be shorter than investment". 


\section{Profit Sharing Concept}

In Muhammad's view, "Profit sharing by foreign terminology (English) is known as profit sharing. Profit in the economic dictionary means profit sharing. Profit sharing according to Indonesian etymology is for profit "(Muhammad, 2002: 101). According to Antonio (2018: 90), "Profit sharing is a system of fund processing in the Islamic economy that is the distribution of business results between the owner of capital (shahibul maal) and the manager (mudharib)".

According to Karim, profit sharing is a form of return (return on return) of the investment contract, from time to time, uncertain and not fixed. The amount of recovery is dependent on the actual results of the business. Thus, it can be said that profit sharing system is one of shariah banking practices (Karim, 2004: 191).

The Concept of Mudharabah

In the view of Huda \& Heykal, mudaraba or qirad belongs to the syirkah category. In the Iraqi language (Iraqi residents used the word mudaraba), while the Hijaz population called it qiradh. In the Qur'an, the word mudaraba is not mentioned clearly with the term mudaraba. Al-Quran only mentions it mushtaq from the word dharaba which there are as many as 58 times (Huda \& Heykal, 2010: 71).

According to Antonio (2018: 95), "Mudaraba comes from the Arabic word taken from the word dharb, meaning to hit or walk. The notion of hitting this run is more precisely the process of a person crashing his foot in running a business ".

According to Sutanto \& Umam, mudaraba or muqaradhah also means traveling for trade matters. Mudharabah means the owner of capital (shahibul maal) to give his / her capital to the workers / traders (mudharib) for trading / cultivation, while the profit of trade is divided according to mutual agreement (Sutanto \& Umam, 2020: 210).

Can be concluded understanding mudharabah is an agreement between two people which consists of the owner of capital (shahibul maal) and the cultivators or who have expertise in doing business (mudharib) and then profit is divided according to the agreement at the beginning of the contract.

Mudharabah is where the owner of the fund provides restrictions to the fund manager, among others, regarding the place, way and or object of investment. Along with its development, there is one type of mudaraba again that is "Mudharabah Musytarakah". Mudharabah mushtarabah is a form of mudaraba where the fund manager includes capital or funds in investment cooperation.

Mudharabah law is permissible in accordance with ijma '(agreement) scholars. In the Qur'an and hadith many found verses and hadith that encourage people to run a business. Here are some Quranic verses and hadiths regarding the advice to do business. "... and those who walk on earth seek some of God's gifts ...." (Q.S. AlMuzammil [73]: 20). "there is no sin for you to seek the gift (rezky of commerce) from your Lord ...” (Q.S. Al-Baqarah [2]: 198). "when it is done praying then you are scattered on earth and seek the gift of god swt ....” (Q.S. Al-Jumu'ah [62]: 10).

"It is narrated from Ibn Abbas that Sayyidina Abbas ibn Abd al-Muttalib if giving funds to his business partners in a mudaraba he requires that his funds are not brought across the ocean, down a dangerous valley, or buy cattle. If it violates the regulation, the person is responsible for the fund. Presented the conditions to the Prophet Muhammad and the Prophet also allow it. "(H.R. Thabrani). Meaning: "From Shalih ibn Shuhaib that Rasulullah SAW said," Three things in it are blessings: hard sell, muqaradhah 
(mudharabah), and mixing wheat with flour for home use, not for sale. "(Ibn Majah no. 2280, Book of At-Tijarah).

\section{Methods}

The method used in this research is associative research (relationship) supported by document analysis approach. In Sujarweni's view, "Association research is a study aimed at finding out the relationship between two or more variables" (Sujarweni, 2020: 49). The type of data used is secondary data with monthly scale (time series), obtained from the official website of BI, OJK and through the official website of PT Bank Muamalat Indonesia. Data analysis used is by using regression analysis of panel data. In this data processing the researcher uses the help of application Eviews 7.

\section{Results and Discussion}

This descriptive statistic is used to see the general description of the data used. The results shows the descriptive statistics of the variables that exist in the panel data modeling in this thesis research.

\section{a. F Restricted (Chow Test)}

The result of Chow test can be seen with prob. for Cross-section F of o,oooo $<0,05$ then by looking at the initial hypothesis is reject Ho or accept Ha means the correct model used is fixed effect model.

\section{b. Hausman Test (Hausman Test)}

The result of hausman test can be seen with prob. for random cross-section $0.0001<0,05$ then by looking at the initial hypothesis is reject Ho or accept Ha means the correct model used is fixed effect model.

So it can be concluded that the model is tep at used in data processing based on two test above that is by using fixed effect model.

Classic Assumption Test

\section{a. Normality}

The results of data processing shows the value of Jarque-Bera of $0.83916<2$ then the normal distributed data means there is no problem, then by looking at the value of the probability of $0.657272>0.05$ then the data is normally distributed so it can be concluded in the test of this normality is not experiencing a problem or data already distributed normally.

b. Autocorrelation

Autocorrelation can be detected through the Durbin-Waston (DW) method of the best model in the selected regression ie the fixed effect model, it can be seen that the DW value of the regression equation is 2.150015 can be seen in table 4.5 below. While the value of Durbin-Watson table with $\mathrm{n}=60$ and $\mathrm{k}=2$, then obtained the value $\mathrm{dL}=$ 1.514 and $\mathrm{dU}=1.652$ so the value of $4-\mathrm{dU}=4-1.652=2.348,4-\mathrm{dL}=4-1.514=2.486$, then the value of DW of the regression model formed in this study are in the autocorrelation free area.

From Figure 1.5 below, it can be seen that the value of DW $=2,150$ is greater than $\mathrm{dU}=1,652$ and smaller than 4 -dU $=2,348$, so it can be concluded that the data used in this research is free from autocorrelation problem. 


\section{c. Heteroscedasticity}

Can be seen in table 1.6 below shows the value of Sum Square Resid (SSR) on the method of fixed effect model (FEM) of 4.56> 6.25 SSR in Generalized Least Square method (GLS), meaning no heteroskedastisitas in this study.

d. Multicolinearity

By looking at the adjusted R-squared value of 0.83 or $83 \%$ and seeing each independent variable significantly affecting the dependent variable can be seen in Table 1.6 below which shows the prob score variable BI Rate and TBH (0.0024 and o, oooo) are all below 0.05 which means significant effect, it means there can be no problem multikolineritas in this research, even if there have been overcome with mengguanaan panel data model.

1. Hypothesis Testing

Results of data processing or estimation conducted using computer program Eviews 7, using the data panel regression method shown in the results that based on the results of calculations performed using the statistics above then obtained multiple linear regression equation regression model as follows:

$$
\begin{aligned}
& \mathrm{Y}=-2,119+3,609 \mathrm{X} 1+0,091 \mathrm{X} 2 \\
& \text { Information: } \\
& \mathrm{Y}=\text { Mudharabah Financing Income } \\
& \mathrm{X} 1=\text { BI Rate } \\
& \mathrm{X} 2=\text { Profit sharing }
\end{aligned}
$$

Based on the regression equation can be analyzed the influence of each independent variable to the dependent variable, constanta a -2.119 states that if the value of BI Rate (X1) and TBH (X2) is constant (o) then the value of mudharabah financing income variable $(\mathrm{Y})$ is $\mathbf{- 2 . 1 1 9}$.

The value of regression coefficient $\mathrm{X} 1$ has positive relation of 3,609 for BI Rate variable, meaning that every $1 \%$ increase of BI Rate, hence income will increase as big as $3,609 \%$ in this case other factor of buffer $p$ fixed.

The value of regression coefficient X2 has a positive relationship of 0.091 for the $\mathrm{TBH}$ variable, which means that every $1 \%$ increase in profit sharing rate, the income will increase by $0.091 \%$, in this case other factors are considered fixed.

a. Test t (Partial Test)

1) Effect of BI Rate on Mudharabah Financing Income

Based on the results in Table 1.6 above the partial regression test ( $t$ test) shows that the regression coefficient value of BI Rate variable is 3,609 with $t$ equal to 3,194 and prob. $0.0024<0.05$ then $\mathrm{Ho}$ is rejected, meaning that the BI Rate affects mudharabah financing income at PT Bank Muamalat Indonesia.

2) Effect of Profit Sharing on Mudharabah Financing Income

Based on the result in table 1.6 above the value of regression coefficient of profit sharing rate (TBH) equal to 0,091 with $t$ equal to 15,097 and prob. $0,0000<0,05$ then Ho is rejected and accept Ha, meaning that profit sharing rate influence mudharabah financing income at PT Bank Muamalat Indonesia.

b. Significant Test F (test together)

In the simultaneous test will be tested the influence of two independent variables together to the dependent variable. Based on the results of statistical tests $\mathrm{F}$ table of output of the above fixed effect model in Table 1.6 Regression output shows prob. F statistic $0.000<0,05(5 \%)$ hence $\mathrm{Ho}$ is rejected, so it can be concluded that 
simultaneously variable of BI Rate and profit sharing rate have significant effect to mudharabah financing income variable at PT Bank Muamalat Indonesia.

c. Adjusted Test R2 (Coefficient of Determination)

Determination Coefficient Analysis (KD) is used to see how much independent variable $(\mathrm{X})$ has an impact on the dependent variable $(\mathrm{Y})$ expressed in percentage. Based on the output table of the fixed effect model in table 1.6 above it can be seen that the Adjusted R-square value of 0.832981 means that together the BI Rate variable and the profit sharing rate have contributed to explain the income of $83.3 \%$ of the mudharabah financing, while the rest equal to $16,7 \%(100 \%-83.3 \%)$ is explained by other variables not studied or excluded in this research model.

Based on the results of this study note that the BI Rate has a positive and significant effect on mudharabah financing revenue, the results of this study in accordance with previous research conducted by Widianto \& Diyani (202O), with the title of research analysis of the influence of BI interest rate on mudharabah financing, shows a significant influence between BI interest rate on mudharabah financing. Then by Fatmawati (202O), with the title of research the influence of BI Rate and Bank soundness level to the level of profit sharing of Bank Syari'ah Mandiri mudharabah period 2008-2020, the result of research shows the variable of BI Rate have positive and significant influence to profit sharing rate of mudharabah.

As we know that the BI Rate is the benchmark interest rate issued by BI which is ultimately followed by an increase in deposit interest rates, loans, deposits in Conventional Banks, hence if interest rates rise then people will tend to save money on Conventional Banks compared Syari'ah Banks because of the high interest rates of savings are in accordance with the classical economic view, but different people who want to do the financing or loan they will think and compare the high loan rates and switch to the Bank Syari'ah to finance dikeranakan The Shari'ah Bank does not set interest but on the principle of profit sharing, therefore the income from Bank Syari'ah financing will increase.

After testing the profit-sharing level has a positive and significant impact on mudharabah financing income, this result is in accordance with previous research conducted by Masduki (2010), with the research title that is the influence of financing share ratio to mudharabah and musyarakah financing volume (case study on PT Bank Syari'ah Mandiri 2009-2018), the results of his research show the ratio of profit sharing financing mudharabah have a positive and significant effect on the volume of mudharabah financing.

Then by Giannini (2020), in his research entitled factors affecting mudharabah financing at a Syari'ah Commercial Bank in Indonesia, one of the factors affecting mudharabah financing is profit sharing, which has a positive effect on mudharabah financing. The result is similar to that done by Iyonu (2020), his research entitled the effect of profit sharing on mudharabah financing (Case study of Sharia Commercial Bank in Indonesia), research shows that the profit-sharing rate affects the amount of mudaraba financing. Badruzaman (2009), with the title of analysis of the influence of third party funds, profit sharing rate, Bank Indonesia wadiah certificates of Bank Syari'ah financing in Indonesia (case study on PT Bank Syari'ah Mandiri), the results of this study indicate that for short the long-term profit-sharing rate shows a significant effect on the amount of mudharabah financing. Andraeny (2018), his research entitled 
analysis of the influence of third party funds, profit sharing, and non-performing financing of profit-sharing financing in syari'ah banking in Indonesia, the results showed the level of profit sharing has a significant effect on the volume of financing based for results in syari'ah banking in Indonesia.

Revenue sharing is one of the distinguishing features between Sharia Bank and Conventional Bank, this profit sharing system is profit sharing after reaching agreement between the customer and the Bank usually in the form of percentage by doing short of profit sharing or by revenue sharing. Therefore, this profit sharing system is one of the contributors to the income of Bank Syari'ah, the higher the profit sharing rate offered by the Bank Syari'ah then the higher the financing income will be obtained because it can be many Indonesian customers who compare the level of profit sharing with interest on Conventional Bank but not a few also customers who do financing or savings in Bank Syari'ah based on religious beliefs.

Effect of BI Rate and Profit Sharing on Mudharabah Financing Income

Based on the result of $\mathrm{F}$ statistic test shows probability $\mathrm{F}$ statistic $0.000<0,05$ (5\%), so it can be concluded that together variable BI Rate and profit sharing rate significantly influence to mudharabah financing income variable. Then based on determination coefficient analysis it can be seen that Adjusted R-square value of o.832981 means that simultaneously variable of BI Rate and profit sharing rate have contribution explain mudharabah financing income equal to $83,3 \%$, while the rest equal to $16,7 \%$ (100\% 83.3\%) was explained by other variables not studied or excluded in this study model.

It is stated above that the BI rate and profit sharing rate affect mudharabah financing income individually or jointly, even though the Sharia Bank does not use the interest system it turns out when the BI Rate increases will have a positive impact on the financing of Bank Syari'ah because the interest on the loan will increase although the interest rate of deposit also goes up in Conventional Bank, so for the prospective customer who will do the loan / financing will prefer to the Bank Syari'ah due to not using the interest system but for the result.

Then for the level of profit sharing itself it is clear that when the Sharia Bank raises the level of profit sharing offered to the customer will make the amount of financing increased by looking at the conditions on the interest rate loans / financing in the Conventional Bank is experiencing an increase then the financing income at the Bank Syari'ah will increase especially mudharabah financing, and proven from result of testing data of R2 indicate that variable of BI Rate and profit sharing rate have influence equal to $83,3 \%$ that number is high enough to influence variable of mudharabah financing income while the rest equal to $16,7 \%$ which may be influenced by other variables not examined in this study.

\section{Conclusion}

Based on the results of research and discussion that has been stated above it can be drawn some. (1) The independent variable of BI Rate has a positive and significant influence on mudharabah financing income. It is proved by the value of regression coefficient of BI Rate of 3,609 with $t$ equal to 3,194 and prob. $0.0024<0.05$. This means that when the BI Rate increases, the proportion of mudharabah financing revenue will go up. (2) The independent variable of profit sharing rate has a positive and significant influence to mudharabah financing income. This is evidenced by the 
value of regression coefficient (TBH) of 0.091 with t equal to 15.097 and prob. of 0.001 $<0.05$. This means that higher profit sharing rate offered and applied by Bank Syari'ah Indonesia kususnya Bank Muamalat Indonesia will increase the amount of mudharabah financing followed by the increase of mudharabah financing income at Bank Muamalat Indonesia. (3) Based on the jointly test independent variables BI rate and profit sharing rate have an influence and significant to the dependent variable of mudharabah financing income, this evidenced by prob. F statistic $0.000<0,05$ (5\%) and with result of testing R2 equal to $83,3 \%$ while the rest equal to $16,7 \%$ (100\% $83,3 \%$ ) explained by other variable not examined or not included in research model this.

\section{REFERENCES}

Aini, Nur. (2020). Business Bank Syariah 2020 Opportunity Continues Soar This is the reason. Diambildarihttp: //www.republika.co.id/berita/ekonomi/syariahekonomi/17/01/18/ojy976382bisnis-bank-syariah-202O-the-possible-to-surge-this-the grounds. Retrieved June 8, 2020.

Andraeny, Dita. (2018). Analysis of the Influence of Third Party Funds, Profit Sharing, and Non Performing Financing Against Sharing Volume Based on Sharia Banking In Indonesia. National Symposium on Accounting to XIV. Aceh. 047. 128.

Antonio, Muhammad Shafi'i. (2018). Bank Syaiah: From Theory to Practice. Jakarta: Gema Insani.

Al-Arif, M. Nur Rianto. (2010). Syari'ah Financial Institutions. Bandung: Loyal Library.

Badruzaman, Najahi. (2009). Influence Analysis of Third Party Funds, Profit Sharing, and Bank Indonesia Wadiah Certificates on Financing of Bank Syariah Indonesia. Thesis: Not Published.

Baltagi, Share. (2005). Econometric Analysis of Panel Data. Third Edition. Jhon Wiley \& Sons.

Bank Indonesia (2020). BI Rate. Taken from http://www.bi.go.id/id/moneter/biRate/penjelasan/Contents/Default.aspx. Retrieved on 20 March 2020.

Bank Muamalat Indonesia (202O). Profile of Bank Muamalat. Taken from http://www.bankmuamalat.co.id/profil-bank-muamalat. Retrieved on 20 March 2020.

Fatmawati, Nur Lailatul (2020). The Influence of BI Rate and Bank Soundness to Bank Syari'ah Mandiri's 2008 Mudharabah Financing Sharing Rate. Thesis: Not Published.

Giannini, Nur Gilang (2020). Factors affecting mudharabah financing in Syari'ah commercial banks in Indonesia. Accounting Analysis Journal, 2 (1), (22526765), 97-103.

Gujarati, Damodar. (2004). Fundamentals of Econometrics. Jakarta: Erland.

Hidayat, Anwar. (2020). Data Panel Regression Tutorial with Eviews. Taken from https://www.statistikian.com/202O/04/tutorial-regresi-data-panel-witheviews.html. Retrieved on May 27, 2020. 
Hidayat, Anwar. (2020). Classic Assumption Test Tutorial with Eviews. Taken from https://www.statisikian.com/2020/02/tutorial-uji-asumsi-klasik-eviews.html. Retrieved on May 27, 2020.

Huda, Nurul \& Heykal, Mohamad. (2010). Islamic Financial Institutions: Theoretical and Practical Review. Jakarta: Kencana.

Iyonu, Mentari Ariesta. (202O). Effect of Profit Sharing on Mudharabah Financing. 14597-14548-1.

Karim, Adiwarman. (2004). Islamic Bank Fiqh \& Financial Analysis. Jakarta: PT. Raja Grafindo Persada.

Karl, E. Case \& Fair, Rai C. (2001). Macroeconomic Principles. Jakarta: Prenhalindo.

Masduki. (2010). Influence of financing share ratio to mudharabah and musyarakah financing volume. Semarang: Not Published.

Mohammed. (2002). Management of Sharia Bank. Yogyakarta: UPP AMPYKPN.

Sugiyono. (2009). Qualitative and Combinative Quantitative Research Methods (Mixed Method). Bandung: Alfabeta.

Sujarweni, V.Wiratna. (2020). Economic Business Research Methodology. Yogyakarta: New Library Press.

Sunariyah. (2018). Introduction to Capital Market Knowledge. Yogyakarta: UPP STIM YKPN.

Sutanto, Herry \& Umam, Khaerul. (2020). Marketing Management of Bank Syari'ah. Bandung: Loyal Library.

Widarjono, Agus. (2007). Econometrics: Theory and Applications for Economics and Business second edition. Yogyakarta: Econisia FE Universitas Islam Indonesia.

Widiyanto, Edo \& Diyani, Lucia Ari. (2020). Analysis of Effect of BI Rate on Mudharabah Financing. Kalbar Socio Journal of Business and Communication, 2 (1), (2356-4385), 98-108. 